\title{
WORKING WITH DISCIPLINARY DISCOURSES IN THE LIGHT OF SYSTEMIC FUNCTIONAL THEORY
}

\author{
(Trabalhando com o discurso de áreas específicas à luz \\ da teoria sistêmico-funcional) \\ Ann Montemayor-Borsinger \\ (Instituto Balseiro/Universidad Nacional de Cuyo Argentina)
}

\begin{abstract}
Genre-based approaches to working with specific disciplinary discourses are reexamined in the light of systemic functional theory. This paper discusses how the Systemic Functional Linguistics (SFL) stratified model of language is used for research writing workshops held at a physics and engineering institute where English dominates as a lingua franca. The paper gives a rationale for a pedagogy focusing on interpersonal and textual strands of meaning. It provides an explicit discussion of the way in which corpus-informed materials have been used with multidisciplinary and mixed-ability groups of scientists. Such an SFL approach to exploiting language corpora for pedagogic purposes shows the pertinence of a tripartite view of language, which provides effective means of developing key aspects of disciplinary discourses by combining subject specialist expertise in the management of content representation in specific fields (ideational meanings), with linguist expertise in evaluating language alternatives for content appraisal (interpersonal meanings) and organisation (textual meanings).
\end{abstract}

KEY-WORDS: research article; disciplinary writing; corpus-informed materials; Systemic Functional Linguistics.

REsumo: As abordagens baseadas em gênero destinadas a trabalhar com discurso especializado são reexaminadas à luz da teoria sistêmico-funcional. Neste artigo discutese como o modelo de linguagem estratificada da Lingüística Sistêmico-Funcional (LSF) éusado em oficinas de produção escrita acadêmica que ocorrem num instituto de engenharia e física onde o inglês é a língua franca dominante. $O$ artigo traz a justificativa para a aplicação de uma pedagogia cujo foco é o entrelaçamento do significado textual e interpessoal. Traz uma discussão explícita da forma pela qual materiais informados por corpus são usados com grupos de cientistas multidisciplinares com habilidades variadas. Tal abordagem sistêmico-funcional de exploração de corpora para fins pedagógicos mostra a importância de uma visão tripartite de linguagem, que oferece meios efetivos para o 
desenvolvimento de aspectos essenciais de discursos disciplinares. Isso se dá ao agregar o conbecimento especializado no gerenciamento da representação de conteúdo em áreas específicas (significados ideacionais) ao conhecimento especializado lingüistico em avaliar as alternativas de linguagem para o conteúdo de avaliatividade (significados interpessoais) e organização (significados textuais).

Palavras-chave: artigo de pesquisa; escrita em áreas específicas; material didático com base em corpus; Lingüistica Sistêmico-Funcional.

\section{Introduction}

More than two decades of sustained interest in genre-based curricula for specific disciplinary discourses has given rise to a number of reappraisals of these socially orientated teaching practices (Belcher 2004; Hyland 2003, 2004; Johns 2003; Johns and Swales 2002; Swales 2004). Genre-based approaches for the teaching of specific discourses have also been a long standing concern of Systemic Functional Linguistics (SFL). SFL theory looks at the different ways the grammar makes new meanings in disciplinary discourses by taking into account the distinctive contributions made by different options in the language system (Halliday and Martin 1993; Halliday 1998, Simon-Vandenbergen et al. 2003). There has also been an increasing number of papers that discuss applications of SFL to the teaching and analysis of disciplinary discourses in Scandinavia (Ventola and Mauranen 1996), Britain (Coffin and Hewings 2004, Hewings 2004, Thompson 2001), Australia (Hood 2004, 2006 and forthcoming, Jones 2004, Woodward-Kron 2007), and the United States (Schleppegrell 2004).

This paper discusses research writing workshops using systemic functional approaches held at a physics and engineering center in Argentina for Spanish-speaking researchers and PhD students. Participants have native-like knowledge of the specific English vocabulary characteristic of their fields, which has been acquired by reading research papers in English throughout their undergraduate and postgraduate studies. What is more, $\mathrm{Ph}$.D. students are expected to have published a minimum of three articles in international journals by the time they get their doctoral degree. English is also used as a lingua franca by visiting lecturers and researchers.

An important systemic functional contribution is the view that texts are a combination of three different strands of meaning - ideational 
meanings that create conceptualizations of experience, concerned here with physics and engineering, interpersonal meanings that enable the communication of these conceptualizations in social exchanges, and textual meanings that organize the ideational and interpersonal dimensions into strings of coherent messages. This view is particularly useful in disciplinary writing contexts, as it helps to promote a kind of division of labor between participants from the 'harder' sciences of physics and engineering with their subject-specific knowledge of ideational content, and ESP practitioners from the 'softer' sciences of linguistics and education with their broader views on evaluation, the expression of interpersonal meanings, and text organization, the expression of textual meanings.

Some years ago when the workshop got underway I was very influenced by process approaches to writing pioneered by Flower and Hayes (1981), and the first workshop was accordingly called "An insight into the Writing Process". The rationale behind this first attempt was to raise awareness on the composing procedures of planning, revising and editing research articles in physics and engineering, which was to be paralleled by writing done by participants.

During the workshop participants did talk about planning, how it should be flexible, how good writers are more willing to change their ideas as they write, and revise their outline as new ideas and arguments develop. But these discussions also indicated that participants had already fashioned their own approaches to planning, and consequently found the discussions rather redundant. Many of them actually seemed to do far more planning and drafting "in their heads" so to speak, than was reported in process approaches whose focus was not necessarily on writing in the harder sciences.

The discussions centering on revising and editing appeared to be more in tune with the needs of the participants. What they found especially interesting were more functional views of language on text flow, the method of development of ideas, and the way established writers managed hedging and evaluation (cf. Berry 1989, Halliday and Martin 1993, Halliday 1998, Hunston and Thompson 2000).

However, participants did not write in parallel with the workshop, as had originally been planned. Most of them were not necessarily writing articles during the four months the course was given. Others felt it useless and time-consuming to present successive drafts for editing to colleagues 
who were not within their area of research and/or whose proficiency in English was not equal to theirs. Those who were writing articles just wanted editing sessions of their final draft on a one to one basis. Individual tutorials were thus introduced as part of the course.

These individual tutorials actually proved to be extremely useful for gathering insights on the kind of difficulties participants were experiencing when writing their research articles. Writing problems were mostly related to the management of interpersonal meanings such as writer stance, and textual meanings of information flow, which are concerned with two of the three strands of meaning distinguished by Systemic Functional Linguistics. This led to a complete reorganization of the workshops, in order to deal more effectively with participant needs. The next section discusses a rationale for using a systemic functional approach in research writing workshops.

\section{A rationale for using Systemic Functional Linguistics}

SFL views language as made up by three main strands of meaning (Halliday 1985, 1994; Halliday \& Matthiessen 2004; Martin 1992; Martin and Rose 2003; Eggins 2004). One has to do with content, the representation of events, and is referred to as ideational meanings. A second strand has to do with transactional meanings, meanings we make to exchange information and negotiate our attitudes and beliefs regarding these events, referred to as interpersonal meanings. The third strand, i.e. textual meanings, organizes ideational and interpersonal meanings into flows of information. This tripartite view of language is particularly useful in the highly specific pedagogical settings discussed here as one can choose to concentrate on the strands of meaning that generally cause more difficulties for non-native student scientists. The focus of the activities presented here is on the evaluation of content (interpersonal meanings) and the flow of content (textual meanings) rather than on the highly subjectspecific ideational content of research articles in physics and engineering.

For SFL interpersonal and textual meanings are realized in text by the lexico-grammatical structures of Mood and Theme. Mood involves examining grammatical subject and verb tense choices, an indication of writer stance and how overtly this writer stance is presented. Theme involves 
examining points of departure of successive clauses, an indication of how the text unfolds, of its Method of Development (Fries 1995).

A challenge is to present the concepts of Mood and Theme in accessible ways that give participants effective tools for understanding how texts mean, without burdening them with unduly complicated concepts. One of the difficulties of working with disciplinary discourses is deciding just how much linguistic metalanguage is actually necessary. In what follows I avoid using the systemic functional wordings of 'Mood' and 'Theme'. Instead, the less technical expressions 'grammatical subject and verb tense' and 'point of departure' are used, as is done in the workshops.

By working on interpersonal meanings of evaluation and negotiation, and on textual meanings of organization, the aim of the workshops is to provide a more complete view of language. This aim has been echoed in research on English for Specific and Academic Purposes where it has been suggested that student scientists generally have adequate knowledge of specific vocabulary, but have problems with their management of appropriate interactive skills and information flow (Swales 1990, Mauranen 1996). Participants that come to the workshops are Spanish-speaking researchers who already publish papers in international refereed journals and $\mathrm{PhD}$ students who have just started publishing. Participants have already got subject-specific knowledge, albeit at varying degrees, and are continuously acquiring more advanced knowledge of scientific representational practices (Bazerman 1998, Davies 1997, Halliday 1998, Hyland 2002, Martin 1998, Johns \& Swales 2002). Against this background they need to complement this specific knowledge by developing an awareness of language that has not only to do with the ideational representation of content. The next section discusses a set of activities that focus on these interactive and organizational language choices.

\section{The activities}

Before workshops start, participants are asked to bring a selection of research article abstracts and introductions from established writers in their field, which they find particularly relevant and interesting. This is a way of building a corpus of socially validated texts for analysis during the workshop, in a similar way to other recent experiments in compiling corpora (Lee and Swales 2006). 
In what follows a selection of six activities are examined, three based on abstracts and three on introductions of research articles. Each activity takes around one hour and a half to complete.

An advantage of abstracts is that they give an important, and sometimes decisive, impression of what a paper is going to be like. Another advantage is their short length, which makes them particularly useful for initial awareness-raising activities on interpersonal and textual meanings. Once these strands of meaning have been introduced and briefly looked at, more detailed work can be done on longer texts. Introductions are useful for this more detailed work because, all things considered, their content tends to be more general than the rest of the research article, which makes them easier to deal with in multidisciplinary groups of physicists and engineers that come from a wide variety of research areas. Furthermore, they involve making complex strategic decisions and nicely illustrate organizational and interactive language choices.

\subsection{Introductory activities based on abstracts}

\section{Activity 1: Choices in grammatical subjects}

The purpose of this activity is to illustrate that within the overall organizational constraints of such short texts, there are a host of language choices that can be made. The present activity focuses on grammatical subjects in each successive clause, which also happen to be their points of departure. In terms of Systemic Functional Linguistics it means looking at 'unmarked Themes' where "there is an integrated choice of an item realizing two functions simultaneously: Subject in the proposition, and Theme in the message" (Halliday 1994: 77), i.e. of interpersonal meanings mapping onto textual meanings. An example of a selection of abstracts that was discussed for different subject choices is the following (points of departure are shown in bold):

Abstract 1

The problem of increasing the understanding of algorithms by considering the foundations of numerical analysis and computer science is considered. The schism between scientific computing and computer science is discussed from a theoretical perspective. These theoretical considerations have an intellectual 
importance when viewing the computer. In particular the legitimacy and importance of models of machines that accept real numbers is considered.

\section{Abstract 2}

This paper defines the Multidisciplinary Design Optimization (MDO) as a new field of research endeavor and as an aid in the design of engineering systems. It examines the MDO conceptual components in relation to each other and defines their functions.

\section{Abstract 3}

We show that Dirichlet-branes, extended objects defined by mixed Dirichlet-Neumann boundary conditions in string theory, break half of the supersymmetries of the type II superstring and carry a complete set of electric and magnetic Ramond-Ramond charges. We also find that the product of the electric and magnetic charges is a single Dirac unit, and that the quantum of charge takes the value required by string duality. This is strong evidence that the Dirchlet-branes are intrinsic to type II string theory and are the Ramond-Ramond sources required by string duality. We also note the existence of a previously overlooked 9-form potential in the IIa string, which gives rise to an effective cosmological constant of undetermined magnitude.

What can be highlighted is that Abstract 1 uses heavily nominalized grammatical subjects as points of departure, with no overt authorial presence. Abstract 2 also uses grammatical subject as points of departure, but these are much 'lighter' and focus on the paper rather than on the matter being discussed. The third abstract is generally seen by participants as particularly interesting because of its overt authorial presence. Regarding the latter, I show them a way of considering its points of departure, following Halliday 1994:58:

\begin{tabular}{|l|l|l|}
\hline We show that & $\begin{array}{l}\text { Dirichlet-branes, extended } \\
\text { objects defined by mixed } \\
\text { Dirichlet-Neumann boundary } \\
\text { conditions in string theory, }\end{array}$ & $\begin{array}{l}\text { break half of the } \\
\text { supersymmetries ... }\end{array}$ \\
\hline $\begin{array}{l}\text { 'Interpersonal' point } \\
\text { of departure, author } \\
\text { projection }\end{array}$ & 'Topical' point of departure & Development \\
\hline
\end{tabular}

Table 1: 
The discussion can be extended, depending on participant needs and interests. Davies $(1988,1997)$ and Gosden $(1993,1996)$ have emphasized the importance of choices in grammatical subject in research papers, because such choices affect the way scientists structure interaction and negotiation with their research community. Both linguists suggest ways of ordering subjects into different domains, going from subjects where authors are entirely invisible to ones where they overtly appear in the text. The three abstracts above illustrate this type of progression. Subjects in the first abstract are research-based entities concerned with the relations between numerical analysis and computer science, where authors are entirely invisible. In the second authors choose their work, i.e. This paper, as grammatical subject, and in the third they appear directly in the text as we. The attention of participants can also be drawn to other language choices and their functional implications. To name just two possible areas of discussion, one can be the implications of choosing grammatical subjects as points of departures rather than other elements such as In this paper... Another can be the differences between using 'heavy' versus 'light' points of departure, i.e. between using The problem of increasing the understanding of algorithms by considering the foundations of numerical analysis and computer science versus This paper or we. These different choices affect for instance the lexical density of scientific texts, with repercussions on information flow and authorial presence (Ventola 1996, Montemayor-Borsinger 2005).

Finally, this type of language awareness has an additional benefit for Spanish-speakers as in their own language grammatical subject is not obligatory, which causes them to sometimes forget it when writing in English. This is particularly noticeable in evaluative comments such as It is clear that or It should be stressed that where an 'empty' it subject would be non existent in Spanish.

\section{Activity 2: Writing on the functions of an abstract}

After looking at sets of abstracts, participants can be asked to write about what they think are the functions of an abstract. The advantage of this activity is that participants produce in one session short texts that can then be used for discussion in following sessions. The disadvantage of working with participants' own productions is that discussions may become too personal and focus on whether the writing is 'correct' or 'incorrect'. 
Before they start writing, it is made clear that the focus is not on grammatical accuracy per se, but on how effectively ideas are presented. Having groups with mixed levels of experience has actually tended to help, as participants generally expect to have different views and are ready for an amount of negotiation.

Participants often find it less threatening to work in pairs. In addition I walk around the classroom and answer any queries participants may have on details of grammar or vocabulary. Here are three different texts written during one of these sessions, which were then discussed:

\footnotetext{
Text 1

What's the purpose of an abstract?

What are abstracts written for?

Why are abstracts written at all?

If a good article begins with an attractive title followed by an easily readable summary, maybe somebody will read it. What I mean is that some papers should be provided with pathetic titles and dull abstracts for everybody's safe (writers meant 'sake'). On the other hand, abstracts save you time. Think for a while: If you had read the abstracts of the bunch of papers you photocopied yesterday, your wastebasket would not be full.
}

\section{Text 2}

An abstract is intended to let the reader grasp the idea of the contents of the paper. In just a little time, readers should be able to decide which papers will be useful for their purposes. Proper abstracts should make this possible.

\section{Text 3}

An abstract could be a help for the reader. In this part of the work he learns what is the work about and what are the results of it. It could be a help for the author too, because you are pressed to extract the main idea and most important results of the work. When the space available for the article is short, it could be a good place to start (and no only explain) the presentation. Many times it is important, as a quick reference, specially for numbers or experimental (numerical) results.

Text 1 and 2 were written by more experienced participants who in the first case commented on the advertising role of abstracts and in the second on the fact that it was the "abstract of an abstract". Text 3, written by doctoral students, stating that when the space available for the article is short, it could be a good place to start (and no only explain) the presentation lead to a discussion where it was finally agreed that this was not the function of an abstract. 


\section{Activity 3: Differences in guidelines on abstracts}

In this activity participants are asked to compare and contrast guidelines on the purpose of abstracts coming from different textbooks on scientific writing, in order to encourage participants to reconsider some of the recommendations made by their teachers or found in text books:

\section{Guideline 1}

Their purpose is to provide a summary of the paper by giving information on (i) what is done in the paper in general (ii) why it was done (iii) what was actually done in practice. (Academic Reading Course, Unit 2: 3)

\section{Guideline 2}

The Abstract should provide a brief summary of each of the main sections of the paper: Introduction, Materials and Methods, Results, and Discussion ......

The Abstract should (i) state the principal objectives and scope of the investigation, (ii) describe the methodology employed, (iii) summarize the results, and (iv) state the principal conclusions. The importance of the conclusions is indicated by the fact that they are often given three times: once in the Abstract, again in the Introduction, and again (in more detail probably) in the Discussion.

Most or all of the Abstract should be written in the past tense, because it refers to work done.

The Abstract should never give any information or conclusion that is not stated in the paper. References to the literature must not be cited in the Abstract (except in rare instances, such as modification of a previously published method). (Day 1989: 28-29)

Participants generally agree with the first description, with most of them having made similar remarks in the previous activity. For the second, they tend to query the claim that Most of all abstracts should be written in the past tense... This leads to a discussion on the sometimes rather partial guidelines available on academic writing and to the importance, when in doubt, of looking up articles by established writers in their own disciplinary fields and assess for themselves what is actually relevant for their own papers.

\subsection{More detailed activities based on research article introductions}

The advantage of working with research article introductions is that they provide longer texts with more ground for discussion on alternative 
language choices. Interactive and organizational aspects can be analyzed more effectively. However, their length also makes them difficult to work with as complete texts in one session. Activities are generally based on shortened, more manageable introductions, which is how they are presented here. Although the purpose of this second series of activities is different from Swales' Move analysis that needs complete introductions, I am still not happy about using incomplete texts because this means disrupting text flow taken as a whole and thus affects some of the textual meanings that are precisely the focus of the workshop. A solution is to present whole introductions as they originally appear in articles for participants to get a global feeling of what they are to work on, even if the actual task only involves some of the paragraphs.

\section{Activity 4: Analysis of tense choice in a 'classic'}

In this activity participants are not told where the text comes from and are asked to choose what they consider is the most adequate tense/ modal in active or passive voice. The aim is to raise awareness on writer stance and evaluation. The original version is reproduced in the Appendix.

Introduction 1: first paragraphs

Although the classical electrodynamic theory (meet) with a considerable amount of success in the description of many atomic phenomena, it (fail) completely on certain fundamental points. It (think) long that the way out of this difficulty (lie) in the fact that there (be) one basic assumption of the classical theory which (be) false, and that if this assumption (remove) and (replace) by something more general, the whole atomic theory (follow) quite naturally. Until quite recently, however, one (have) no idea of what this assumption (be).

A recent paper by Heisenberg (provide) the clue to the solution of this question, and (form) the basis of a new quantum theory. According to Heisenberg, if $x$ and $y$ (be) two functions of the co-ordinates and momenta of a dynamical system, then in general $x y$ (be) not equal to $y x$. Instead of the commutative law of multiplication, the canonical variables $q_{r} p_{r} \quad(r=1 \ldots u)$ of a system of $u$ degrees of freedom (satisfy) the quantum conditions, which (give) by the author in the form

$$
\begin{aligned}
& q_{r} q_{s}-q_{s} q_{r}=0 \\
& p_{r} p_{s}-p_{s} p_{r}=0 \\
& q_{r} p_{s}-p_{s} q_{r}=0 \\
& q_{r} p_{r}-p_{r} q_{r}=i h
\end{aligned} \quad(r \neq s)
$$


where $\mathrm{i}$ (be) a root of -1 and $h$ (be) a real universal constant, equal to $(2 \mathrm{p})^{-1}$ times the usual Planck's constant. These equations (be) just sufficient to enable one to calculate $x y-y x$ when $x$ and $y$ (be) given functions of the $p$ 's and $q$ 's, and (be) therefore capable of replacing the classical commutative law of multiplication. They (appear) to be the simplest assumptions one (make) which (give) a workable theory.

The text was written in 1926 by Dirac, when he was a senior research student of St. John's College, Cambridge. He is one of the founders of quantum mechanics and of modern quantum electrodynamics, and received the Nobel Prize in 1933. In several instances, participants put plausible alternative tenses to the ones used by Dirac. This shows that even in a constrained activity where only tense has to be replaced, there are strategic choices to be made depending on the context of production of the text. An example is the conditional in lines 4-5. Participants mostly choose a first conditional, i.e. if this assumption is removed and replaced by something more general, the whole atomic theory will follow quite naturally, where Dirac had originally written if this assumption were removed and replaced by something more general, the whole atomic theory would follow quite naturally. This is a good illustration of aspect, of how scientific writers position themselves. At the time when Dirac wrote this paper, he was introducing these ideas, and they did not have the degree of certainty they have now. A similar example is illustrated by the last two verbs of the last sentence. Participants are generally inclined to choose They appear to be the simplest assumptions one can make which give a workable theory, instead of Dirac's could make and would give, which he had further hedged at the time by using They appear to be as point of departure of the sentence.

According to the groups involved, discussions sometimes lead to aspects such as how present and past tenses tend to be associated with time in general English courses, when in scientific writing they are best associated with the generality and relevance of events (Halliday 1978:132, Martin 1992:18, Swales 1990:152). Simple exercises such as the one presented above illustrate how tense choices indicate differing beliefs and attitudes a particularly important point for writers of articles, who need to be able to position themselves strategically in their research contexts (cf. Hunston 1994, Hunston and Thompson 2002, Hyland 1998, Martin and Halliday 1993, Martin and Veel 1998, Montemayor-Borsinger forthcoming). 
Activity 5: A more detailed look at points of departure and grammatical subjects

An essential aspect of writing up research is the effective management of information flow, which involves the selection and ordering of points of departure of the successive clauses that build up whole texts. These aspects related to textual meanings of organization are briefly introduced in the activities based on short abstracts. Awareness of how texts unfold is then further developed with longer texts, with the help of the following table:

\begin{tabular}{|c|c|c|c|}
\hline \multicolumn{2}{|c|}{$\begin{array}{c}\text { Point of departure } \\
\text { of the clause }\end{array}$} & \multicolumn{2}{c|}{ Development of the clause } \\
\hline & Subject & Verb & \\
\hline & & & \\
\hline & & & \\
\hline
\end{tabular}

Table 2:

I designed this table in the systemic functional tradition to help participants make quick analyses of texts (cf. Berry 1989, 1996; Davies 1988, 1997; Martin 1985; Martin et al. 1997). Its advantage is that it allows the simultaneous examination of the realizations of both interpersonal and textual strands of meaning. The headings 'Point of departure of the clause' and 'Development of the clause' appearing in the first row relate to a systemic functional analysis of textual meanings, i.e. of Theme, the point of departure of the message, and Rheme, the remainder of the message in which Theme is developed (Halliday and Matthiessen 2004: 64). The headings in the second row relate to a systemic functional analysis of interpersonal meanings, i.e. of grammatical subject, the 'resting point' of the argument (Halliday and Matthiessen 2004: 118), and finite verb. By the latter Halliday means the part of the verb that anchors a proposition to the time of speaking and/or to the judgment of the speaker by tense and modality (Halliday and Matthiessen 2004: 115). Table 3 shows the analysis resulting from the beginning of another introduction:

Introduction 2: first two paragraphs

During the last decade, a set of previously disjointed ideas and tools has crystallized into a new technology with a cohesiveness and distinct character that give it 
characteristics of a new engineering discipline. This discipline is unique in its role in engineering design where it acts as an agent binding together the other engineering disciplines involved. The new discipline is often called the Multidisciplinary Design Optimization (MDO), e.g. Ref. 1, and will be referred to by this name herein. Alternative names such as Multidisciplinary Analysis and Optimization (MAO) and Multidisciplinary Design Methodology or Technology (MDM or MDT) have also been proposed.

The purpose of this paper is to introduce the definition of MDO and of its principal conceptual components which are Design-Oriented Analysis, Approximation Concepts, System Mathematical Modeling, Design Space Search, Optimization Procedure, and Human Interface as shown in Fig. 1. The paper examines functionality and mutual relationships of these components and examines their internal structure also depicted in Fig. 1. Without attempting a comprehensive survey, selected references will be quoted to support the above discussion.

\begin{tabular}{|c|c|c|c|}
\hline \multicolumn{2}{|c|}{ Point of departure of the clause } & \multicolumn{2}{|c|}{ Development of the clause } \\
\hline & Subject & Verb & \\
\hline \multicolumn{4}{|l|}{ First paragraph } \\
\hline \multirow[t]{3}{*}{$\begin{array}{l}\text { During the last } \\
\text { decade, }\end{array}$} & $\begin{array}{l}\text { a set of previously } \\
\text { disjointed ideas and tools }\end{array}$ & has crystallized & $\begin{array}{l}\text { into a new technology } \\
\text { with a cohesiveness } \\
\text { and distinct character } \\
\text {... }\end{array}$ \\
\hline & This discipline & is & $\begin{array}{l}\text { unique in its role in } \\
\text { engineering design } \\
\text { where it acts as an } \\
\text { agent binding ... }\end{array}$ \\
\hline & The new discipline & is often called & $\begin{array}{l}\text { the Multidisciplinary } \\
\text { Design Optimization } \\
\text { (MDO), e.g. Ref. 1, }\end{array}$ \\
\hline \multirow[t]{2}{*}{ And } & (the new discipline) & will be referred to & by this name herein. \\
\hline & $\begin{array}{l}\text { Alternative names such } \\
\text { as Multidisciplinary } \\
\text { Analysis and } \\
\text { Optimization (MAO) and } \\
\text { Multidisciplinary Design } \\
\text { Methodology or } \\
\text { Technology (MDM or } \\
\text { MDT) }\end{array}$ & have also been proposed. & \\
\hline \multicolumn{4}{|l|}{ Second paragraph } \\
\hline & The purpose of this paper & is & $\begin{array}{l}\text { to introduce the } \\
\text { definition of MDO ... }\end{array}$ \\
\hline & The paper & examines & $\begin{array}{l}\text { functionality and } \\
\text { mutual relationships of } \\
\text { these components }\end{array}$ \\
\hline And & (the paper) & examines & $\begin{array}{l}\text { their internal structure } \\
\text { also depicted in Fig. } 1 \text {. }\end{array}$ \\
\hline $\begin{array}{l}\text { Without attempting a } \\
\text { comprehensive } \\
\text { survey, }\end{array}$ & selected references & will be quoted & $\begin{array}{l}\text { to support the above } \\
\text { discussion. }\end{array}$ \\
\hline
\end{tabular}

Table 3: Analysis of Introduction 2 
Possible items for discussion are the type of circumstantials (During the last decade..., Without attempting a comprehensive survey) that often precede grammatical subjects and their corresponding functions, such as signaling shifts and changes in the text, or organizing arguments, etc.. Another is how grammatical subjects form different lexical chains in each paragraph: in the first, all the subjects are concerned with the new discipline, and in the second with the paper. The discussion can be further extended to looking at how information generally flows from 'given' points of departure to 'new' developments (Daneš 1974: 118; Halliday and Matthiessen 2004:93), which is how the first paragraph is organized. The first sentence starts with the given information During the last decade a set of ... and then develops the new information ... a new technology with a cohesiveness and distinct character that give it characteristics of a new engineering discipline. The second point of departure This discipline has now become given and in turn introduces new concepts related to its uniqueness in engineering design. The third and fourth points of departure are also concerned with the discipline which has become given information and introduce as new information its name. Finally, the last point of departure takes up again the idea of naming, i.e. Alternative names such as .... This paragraph combines nicely what Daneš (1974) calls 'linear' and constant thematic progression:

\begin{tabular}{|r|l|l|l|}
\hline 1 & $\begin{array}{l}\text { During the last decade, a set of } \\
\text { previously disjointed ideas and } \\
\text { tools }\end{array}$ & has crystallized & $\begin{array}{l}\ldots \text { characteristics of a new } \\
\text { engineering discipline. }\end{array}$ \\
\hline 2 & This discipline & is & unique in its role ... \\
\hline 3 & The new discipline & is often called & the MDO ... \\
\hline 4 & and (the new discipline) & $\begin{array}{l}\text { will be referred } \\
\text { to }\end{array}$ & by this name herein. \\
\hline 5 & $\begin{array}{l}\text { Alternative names such as } \\
\text { MAO and MDM or MDT }\end{array}$ & $\begin{array}{l}\text { have also been } \\
\text { proposed. }\end{array}$ & \\
\hline
\end{tabular}

Table 4: Analysis of information flow in the first paragraph of Introduction 2

There is a lineal progression from 1 to 2 , where the new information in 1 becomes the point of departure in 2 . After that, points of departure in 2, 3 and 4 remain constant. Finally the issue of naming the new discipline developed in 4 is taken up as a point of departure in 5, using again a lineal progression. 
Participants can be asked to look at information flow in their own writing and examine ways of improving it. First, they can be given very simple texts to edit in class, of the type produced by students in TOEFL or IELTS preparation courses. An example is the following sentence that introduces a paragraph comparing Geneva with other cities: Considering that it is the safest, the least noisy, has a reasonable level of air pollution and is the best supplied with basic services (especially education), Geneva provides the best environment to live in. By just making Geneva the point of departure of this small text, information flow is considerably improved: Considering that Geneva is the safest, the least noisy, (...) this city provides the best environment to live in.

\section{Activity 6: Authorial presence in text}

During the workshops authorial presence is also further explored in longer texts. An introduction that offers very different choices from the previous one is shown in the extract below. Here the author visibly appears in the text:

Introduction 3: first paragraphs

I would like to discuss a problem already raised by John von Neumann in 1951 ("The General and Logical Theory of Automata," in [von Neumann, 1963]). Its relevance compels me to quote once more from this article ........

Von Neumann has anticipated what I like to call the conflict between scientific computation and computer science. Two subjects with many common goals have grown apart. On the theoretical side especially, this conflict seems broad and deep. For example, numerical analysts (I speak of numerical analysts as the theorists of scientific computation) have a disdain for Turing machines. On the other side, computer scientists often minimize the importance of calculus in the college curriculum. These are just signs of a bigger schism. The following little table illustrates the contrast I am trying to make.

If we do a 'quick and dirty' analysis helped by the table we get: 


\begin{tabular}{|c|c|c|c|}
\hline \multicolumn{2}{|c|}{ Point of departure of the clause } & \multicolumn{2}{|c|}{ Development of the clause } \\
\hline & Subject & Verb & \\
\hline & I & would like & $\begin{array}{l}\text { to discuss a problem } \\
\text { already raised by John } \\
\text { von Neumann in } 1951\end{array}$ \\
\hline & Its relevance & compels & $\begin{array}{l}\text { me to quote once more } \\
\text { from this article } \ldots . . .\end{array}$ \\
\hline & Von Neumann & has anticipated & \\
\hline \multirow[t]{2}{*}{ What } & I & like to call & $\begin{array}{l}\text { the conflict between } \\
\text { scientific computation } \\
\text { and computer science. }\end{array}$ \\
\hline & $\begin{array}{l}\text { Two subjects with many } \\
\text { common goals }\end{array}$ & have grown apart. & \\
\hline $\begin{array}{l}\text { On the theoretical } \\
\text { side especially, }\end{array}$ & this conflict & seems & broad and deep. \\
\hline For example, & $\begin{array}{l}\text { numerical analysts (I } \\
\text { speak of numerical } \\
\text { analysts as the theorists } \\
\text { of scientific } \\
\text { computation) }\end{array}$ & have & $\begin{array}{l}\text { a disdain for Turing } \\
\text { machines. }\end{array}$ \\
\hline \multirow[t]{4}{*}{ On the other side, } & computer scientists & often minimize & $\begin{array}{l}\text { the importance of } \\
\text { calculus in the college } \\
\text { curriculum. }\end{array}$ \\
\hline & These & are & $\begin{array}{l}\text { just signs of a bigger } \\
\text { schism. }\end{array}$ \\
\hline & The following little table & illustrates & the contrast \\
\hline & $\mathrm{I}$ & am trying & to make \\
\hline
\end{tabular}

Table 5: Analysis of Introduction 3

Table 5 shows a number of different subjects, interspersed by very strong authorial presence with $I$ used four times. In contrast, subject choices in the previous introduction clearly focused on discipline (first paragraph) and paper (second paragraph). Both introductions were written by established researchers, and represent quite a good contrast of the type of language choices scientists can make. However, for Spanish-speakers the choices involved in the last text are perceived as extremely marked, especially as grammatical subject is not obligatory in their language. Spanish tends to have more use for impersonal/passive constructions in professional settings. Participants have also linked this with writer status and the fact that more established writers may feel more confident about appearing so overtly. 


\subsection{Ideas for future activities}

In final sessions participants discuss how workshops could be improved. Recently, a group of more experienced participants stated they would like to work on developing their evaluation and negotiation skills. They related these skills specifically to refereeing other people's work, and to replying to referees about their own work. When having to deal with highly evaluative texts such as referee reports, they felt that being non native speakers was much more of a hindrance than when writing the research article itself. A corpus of referee reports from physics and engineering is now being collected for further work on interpersonal meanings.

\section{Discussion}

Designing and conducting research writing workshops is a special challenge that can be met in many different ways. This paper has argued for a genre-based approach in the systemic functional tradition to raise awareness on how ideational, interpersonal and textual meanings are realized in texts. A key factor is participants' ideational 'content' knowledge, which implies both their help in building a corpus of texts from established writers in their fields, and their many contributions during workshops. Within a systemic functional perspective, when designing research writing activities it is essential to include the social context of the disciplinary text under study. Participants belong to this social context, and know where their texts come from and what their specific content is about. Here I have argued that given the high specificity of research articles, academic English practitioners' comparative advantage lies more in discussing meanings related to evaluation and organization of content rather than to content representation per se. The sample of six activities reviewed in the present paper focuses precisely on these interpersonal and textual aspects, but always in the knowledge that for pedagogical reasons we are separating meanings that are actually combined together in language.

Furthermore, a systemic functional approach has the advantage of using a theoretical framework that has shown to be of interest to subject specialists from disciplines other than education or linguistics. In my experience, by making explicit and facilitating a kind of division of labor 
between subject specialists in the 'harder' sciences of physics and engineering that come to the workshop and academic English practitioners from the 'softer' sciences, Systemic Functional Linguistics offers interesting avenues of cooperation between very different academic communities by promoting a better understanding of how disciplinary texts mean as they do.

Recebido em maio de 2008. Aprovado em julho de 2008. E-mail: aborsinger@gmail.com

\section{REFERENCES}

BAZERMAN, C. 1998. Emerging perspectives on the many dimensions of scientific discourse. In J.R. Martin \& R. Veel (eds.). Reading Science: Critical and Functional Perspectives on Discourses of Science (pp. 15-28). London: Routledge.

Belcher, D. 2004. Trends in teaching English for Specific Purposes. Annual Review of Applied Linguistics, 24: 165-186.

BERRY, M. 1989. Thematic options and success in writing. In C.S. Butler, R.A. Cardwell \& J. Channel (eds.). Language E Literature - Theory $\mathcal{E}$ Practice: A Tribute to Walter Grauberg (pp. 62-80). Nottingham: University of Nottingham Monographs in the Humanities VI. . 1996. What is Theme? A(nother) personal view. In: M. Berry, C. Butler, R. Fawcett \& G. Huang (eds.). Meaning and form: systemic functional interpretations (pp. 1-64). Norwood New Jersey: Ablex Publishing Company.

Coffin, C. \& Hewings, A. 2004. IELTS as a preparation for tertiary writing: distinctive interpersonal and textual strategies. In: L. Ravelli \& R. Ellis (eds.). Analysing Academic Writing (pp. 153-171). London: Continuum.

Davies, F. 1988. Reading between the lines: Thematic choice as a device for presenting written viewpoint in academic discourse. The ESPecialist, 9(1/2): 173-200.

. 1997. Marked Theme as a Heuristic for Analysing Text-Type, Text and Genre. In: J. Pique \& D.J. Viera (eds.). Applied Linguistics: Theory and Practice in ESP (pp. 45-79). Valencia: Valencia University Press. 
Day, R. 1989. How to write and Publish a Scientific Paper (third ed.). Cambridge: Cambridge University Press.

DANeš, F. 1974. Functional sentence perspective and the organisation of the text- In F. Daneš (ed.). Papers on Functional Sentence Perspective (pp. 106-128). Prague, Mouton: Academic Publishing House, Czech Academy of Science.

DirAC, P.A.M. 1926. Quantum mechanics and a preliminary investigation of the hydrogen atom. Proc. Roy. Soc. A110. Reproduced in B.L. Van Der Waerden (ed.) 1968. Sources of Quantum Mechanics (pp. 417-427). New York: Dover Publications.

EgGins, S. 2004. An Introduction to Systemic Functional Linguistics (second ed.). New York, London: Continuum International Publishing Group.

Fries, P. 1995. Themes, Methods of Development, and Texts. In: R. Hasan \& P Fries (eds.). On Subject and Theme: A Discourse Functional Perspective (pp. 317-359). Amsterdam: John Benjamins Publishing Company.

Flower, L. \& HaYes, J. 1981. A cognitive process theory of writing. College Composition and Communication, 32: 365-387.

Gosden, H. 1993. Discourse Functions of Subject in Scientific Research Articles. Applied Linguistics, 14/1: 56-75. . 1996. A Genre-based Investigation of Theme: Product and Process in Scientific Research Articles Written by NNS Novice Researchers. Monographs in Systemic Linguistics 7. University of Nottingham.

Halliday, M.A.K. 1978. Language as social semiotic. The social interpretation of language and meaning. London: Edward Arnold. 1985/1994. An Introduction to Functional Grammar. London: Edward Arnold. 1998. Things and Relations. In: J.R. Martin \& R. Veel (eds.). Reading Science: Critical and functional perspectives on discourses of science (pp. 185-235). London: Routledge.

Halliday, M.A.K. \& Martin, J.R. 1993. Writing Science: Literacy and Discursive Power. London: The Falmer Press.

Halliday, M.A.K. \& Matthiessen, C.M.I.M. 2004. An Introduction to Functional Grammar (third ed.). London: Edward Arnold.

Hewings, A. 2004. Developing discipline-specific writing: an analysis of undergraduate geography essays. In: Ravelli, L \& Ellis, R (eds.) Analysing academic writing: Contextualised frameworks (pp. 131-152). London: Continuum. 
Hood, S. 2004. Managing attitude in undergraduate academic writing: a focus on the introductions to research reports. In: Ravelli, L \& Ellis, R (eds.) Analysing academic writing: Contextualised frameworks (pp. 24-44). London: Continuum. 2006. The persuasive power of prosodies: Radiating values in academic writing'. Journal of English for Academic Purposes, 5/1: 37-49. . (forthcoming) Texturing interpersonal meanings in academic research writing: periodic pulses of value. In: G. Forey \& G. Thompson (eds.) Text type and texture. London: Equinox.

Hunston, S. 1994. Evaluation and organization in a sample of written academic discourse. In M. Coulthard (ed.). Advances in Written Text Analysis (pp. 191-218). London: Routledge.

Hunston, S. \& Thompson, G. 2000. Evaluation in Text: Authorial Stance and the Construction of Discourse. Oxford: Oxford University Press.

Hyland, K. 1998. Persuasion and Context: The Pragmatics of Academic Metadiscourse. Journal of Pragmatics, 30: 437-455. . 2002. Genre: Language, Context, and Literacy. Annual Review of Applied Linguistics 22: 113-135.

. 2003. Genre-based pedagogies: A social response to process. Journal of Second Language Writing, 12: 17-29. .2004. Genre and second language writing. Ann Arbor, Michigan: The University of Michigan Press.

JoHns, A.M. 2003. Genre and ESL/EFL composition instruction. In: B. Kroll (ed.). Exploring the dynamics of second language writing (pp. 195217). Cambridge: Cambridge University Press.

Johns, A.M. \& Swales, J.M. 2002. Literacy and disciplinary practices: opening and closing perspectives. Journal of English for Academic Purposes 1: 13-28.

JONES, J. 2004. Learning to write in the disciplines: the application of systemic functional linguistic theory to the teaching and research of student writing. In: Ravelli, L \& Ellis, R (eds.) Analysing academic writing: Contextualised frameworks (pp. 254-273). London: Continuum.

LeE, D. \& Swales, J. 2006. A corpus-based EAP course for NNS doctoral students: Moving from available specialized corpora to self-compiled corpora. English for Specific Purposes 25: 56-75.

MARTIN, J.R. 1985. Factual writing: exploring and challenging social reality. Oxford: Oxford University Press. 
1992. English Text: System and Structure. Amsterdam: John Benjamins.

Martin, J. R.; Matthiessen C.M.I.M \& Painter C. 1997. Working with Functional Grammar. London: Edward Arnold.

Martin, J.R. \& Rose, D. 2003. Working with Discourse: Meaning beyond the clause. London and New York: Continuum.

Mauranen, A. 1996. Discourse Competence - Evidence from Thematic Development in Native and Non-native Texts. In: E. Ventola \& A. Mauranen (eds.). Academic Writing: Intercultural and Textual Issues (pp.195-230). Amsterdam: John Benjamins.

Montemayor-Borsinger, A. 2005. Authorial Development in Research Writing: coding changes in grammatical subject The ESPecialist 26/2: 82-104.

(forthcoming) Text-type and Texture: the potential of Theme for the study of research writing development. In: G. Thompson \& G. Forey (eds.) Text-type and Texture London: Equinox Publishing Ltd.

SChleppegrell, M.J. 2004. Technical writing in a second language: the role of grammatical metaphor. In: Ravelli, L \& Ellis, R (eds.) Analysing academic writing: Contextualised frameworks (pp. 172-189). London: Continuum.

Simon-Vandenbergen, A., Taverniers, M. \& Ravelli, L. 2003 Grammatical Metaphor: Views from systemic functional linguistics. Amsterdam: John Benjamins.

Swales, J. 1981. Aspects of Article Introductions. Aston Research Report No 1 University of Aston. 1990. Genre Analysis: English in Academic and Research Settings. Cambridge: Cambridge University Press. 2004. Then and now: a reconsideration of the first corpus of scientific English. Iberica, 8: 5-21.

Thompson, G. 2001. Interaction in academic writing: to argue with the reader. Applied Linguistics 22(1): 58-78.

University of Liverpool Academic Reading Course English Language Unit.

Ventola, E. 1996. Packing and Unpacking of Information in Academic Texts. In: E. Ventola \& A. Mauranen (eds.). Academic Writing: Intercultural and Textual Issues (pp.153 -194). Amsterdam: John Benjamins.

Ventola, E. \& Mauranen, A. (eds.) 1996. Academic Writing: Intercultural and Textual Issues (pp.153 -194). Amsterdam: John Benjamins. 
WoOdWARd-Kron, R. 2004 'Discourse communities' and 'writing apprenticeship: an investigation of these concepts in undergraduate Education students' writing. Journal of English for Academic Purposes 3/ 2: 139-161.

\author{
APPENDIX \\ Activity 7: The original text \\ Quantum mechanics and a preliminary investigation of the \\ hydrogen atom \\ P.A.M. Dirac
}

\title{
1. The algebraic laws governing dynamical variables
}

Although the classical electrodynamic theory meets with a considerable amount of success in the description of many atomic phenomena, it fails completely on certain fundamental points. It has long been thought that the way out of this difficulty lies in the fact that there is one basic assumption of the classical theory which is false, and that if this assumption were removed and replaced by something more general, the whole atomic theory would follow quite naturally. Until quite recently, however, one has had no idea of what this assumption could be.

A recent paper by Heisenberg provides the clue to the solution of this question, and forms the basis of a new quantum theory. According to Heisenberg, if $x$ and $y$ are two functions of the co-ordinates and momenta of a dynamical system, then in general $x y$ is not equal to $y x$. Instead of the commutative law of multiplication, the canonical variables $q_{r} p_{r} \quad(r=1 \ldots u)$ of a system of $u$ degrees of freedom satisfy the quantum conditions, which were given by the author in the form 


$$
\begin{aligned}
& q_{r} q_{s}-q_{s} q_{r}=0 \\
& p_{r} p_{s}-p_{s} p_{r}=0 \\
& q_{r} p_{s}-p_{s} q_{r}=0 \quad(r \neq s) \\
& q_{r} p_{r}-p_{r} q_{r}=i h
\end{aligned}
$$

where $i$ is a root of -1 and $b$ is a real universal constant, equal to $(2 p)^{-1}$ times the usual Planck's constant. These equations are just sufficient to enable one to calculate $x y-y x$ when $x$ and $y$ are given functions of the $p$ 's and $q$ 's, and are therefore capable of replacing the classical commutative law of multiplication. They appear to be the simplest assumptions one could make which would give a workable theory. 